\title{
Use of biodegradable polymer for development of environmental tracers: a bibliometric review
}

\author{
Adriana Marques $^{1 *}$ (i) and Sandra Maria da Luz ${ }^{2}$ (D) \\ ${ }^{1}$ Instituto Federal de Educação, Ciência e Tecnologia de São Paulo - IFSP, Itapetininga, SP, Brasil \\ ${ }^{2}$ Faculdade do Gama, Universidade de Brasilia - UnB, Brasilia, DF, Brasil \\ *adrimarks@ifsp.edu.br
}

\begin{abstract}
Qualitative and quantitative measuring in water bodies, nuclear medicine, agriculture, and world oil production use tracers to monitor, evaluate and continuously improve their processes. The bibliometric information about the past and the future of artificial tracers, to monitor surface and groundwater by using sustainable biodegradable materials it will be important for future generation. To fulfil this purpose, bibliometric literature analysis has been considered as a solution to identify research areas that need to be improved. The results of this paper showed that even with the increase in research in biopolymers, and the use of artificial tracers, academic development is still not significant. The United States, China, and Germany are the top publishers in this field however, there is no country that constantly develops research in these areas concomitantly using biodegradable polymers. Because of that, this field could be further explored, globally using innovative techniques and materials for new tracers.
\end{abstract}

Keywords: polyhydroxybutyrate, polymeric membranes, nanocellulose, biodegradable materials, tracers.

How to cite: Marques, A., \& Luz, S. M. (2021). Use of biodegradable polymer for development of environmental tracers: a bibliometric review. Polimeros: Ciência e Tecnologia, 31(1), e2021012. https://doi.org/10.1590/0104-1428.00221

\section{Introduction}

Contamination of surface water and groundwater is an invisible threat to global development goals ${ }^{[1]}$. Over time, drinking water has become an indicator of life quality in contemporary society and a factor of social and economic development ${ }^{[2]}$. Waterborne diseases, lack of water quality for communities and contamination in watercourses are challenges that have been addressed by the development of research regarding new materials and technologies in the fields of nuclear medicine and pharmacology ${ }^{[3]}$. It would be necessary to develop new clinical protocols, new drugs and environmental evaluation to monitor changes in aquatic ecosystems ${ }^{[4]}$. This problem arises because of the need to monitor possible sources of water pollution ${ }^{[5]}$.

One of the tools used in the hydrogeological environment for monitoring surface and groundwater are artificial tracers ${ }^{[4,6]}$. The term 'tracer' refers to any product or substance that, when incorporating the mass of another substance, allows analysis of its behaviour relating to physical or chemical processes, in addition to being able to identify the dynamic behaviour of a flow system ${ }^{[7,8]}$. The tracers must be conservative and innocuous and need to have a low impact on the environment, in addition to having a relevant cost-benefit ${ }^{[9,10]}$.

Meanwhile environmental tracers are defined as ambient, natural or anthropogenic compounds or materials that are widely distributed in the environment, the artificial tracer are defined as a substances injected in the site with the scale of application limited to the space and time such as fluorescence, salt, drifting particles (dye) and radioactive tracers ${ }^{[4,8]}$.

Because of the various types of artificial and environmental tracers mentioned, they can provide hydrological, ecological, and biogeochemical information that allow an understanding of the interactions of surface water and groundwater ${ }^{[6]}$. Tracers allow hydrometric observations of the course of diffuse water contamination, based on the scale of the site studied and the type of tracer chosen ${ }^{[6,9]}$. Tracers can be made by using different materials with different chemical, optical, colour, fluorescence, gaseous, radioactive, saline, and biological properties ${ }^{[7]}$.

Currently, tracers are used in several areas of knowledge, with a wide range of technological and scientific applications. In nuclear medicine, they are the contrasting products used in magnetic resonance imaging (MRI) and are used to improve the image quality for staining and identifying tumours, etc. The basis of this contrast is a rare earth element called Gadolinium, chelated with diethylenetriaminepentaacetic $\operatorname{acid}(\mathrm{DTPA})^{[10,11]}$.

In the biological sciences, tracers are used to measure variations in nutrients received by plant sap and they appear in agriculture, increasing productivity by determining the relevant parameters for irrigation and application of pesticides $^{[12]}$. In geoscience, geology and hydrology, tracers are widely used for environmental monitoring, being one of the most relevant applications for the monitoring of surface and groundwater ${ }^{[13-16]}$. 
In engineering, tracers are used in hydraulics, to characterize reservoir recharge and refilling ${ }^{[6,17]}$. Also they were used in this field to integrate hydrogeochemical, hydrogeological data to understand groundwater flow for a karstified aquifer system ${ }^{[18-21]}$. In innovative engineering research areas multiple-tracer data are tools that can bring information by using parameter models regarding the dispersion of fractured and carbonated rocks and also they can show how ages could be used to calibrate groundwater models ${ }^{[22-25]}$; Not only, traditional stable isotopic tracers as $\mathrm{H}, \mathrm{O}, \mathrm{N}$ and $\mathrm{C}$ are used but also $\mathrm{Li}, \mathrm{Zn}$ and $\mathrm{Cu}$ in the last 20 years have emerged as a new tracers ${ }^{[26,27]}$.

In civil engineering, tracers are used to assess soil contamination by diesel, gasoline, and kerosene ${ }^{[28-30]}$; Besides that, Hillebrand et al. ${ }^{[31]}$ states that pesticides transportation in wetland, groundwater ad surface water interfaces could be investigated by artificial tracers. In electronics and aeronautics, fluorescent tracers work as sensors or detectors of emissions ${ }^{[32]}$. In chemistry, fluorescence detectors are used in chromatographic systems ${ }^{[33-35]}$.In the field of oil and gas production, they use tracers in various exploration processes, throughout the life of a field ${ }^{[36-38]}$. However, there is a shortage of economically viable and commercially accessible tracers for applications where there is biphasic flow (where water predominates over oil) with large volumes of injection and production ${ }^{[30,39]}$.

The application of tracers to different areas of knowledge via numerous ways and forms also raises questions about the toxicity and impact on the environment ${ }^{[40,41]}$. Regarding to the injection of artificial tracers in the environment, many studies ${ }^{[42,43]}$ shown the harmless of Uranine, Eosine, Pyranine and Naphthiolate and also the toxicity of Rhodamine group even though they have been used in grams or kilograms they still live the residual contamination ${ }^{[44]}$. Because of that, firstly some tracers have already been banned due to potential harm to human health and the environment and secondly the planning of tracers experiment with tolerable daily intake (TDI) it must be considering for the future regarding their possibility of bio-accumulative or carcinogenic to nature ${ }^{[14,45]}$.

Biodegradable tracers could be an alternative for overcoming such environmental concerns. In order to be clear about the information regarding BCM in this paper, some definitions are necessary. The definition of a composite membrane $(\mathrm{CM})$ is one which consists of at least two structural elements made from different materials ${ }^{[46]}$. Usually in a CM, there is an asymmetric structure with layers that could be made of porous or non-porous materials ${ }^{[47]}$. These layers could have different properties depending on the structural elements and the functionalized or doped process ${ }^{[48]}$. Besides this, $\mathrm{CM}$ can be prepared by numerous processes such as blending ${ }^{[49]}$, coating ${ }^{[50]}$, casting ${ }^{[51]}$, or electrospinning ${ }^{[52,53]}$.

Regardless of the production model of the membranes, nanocomposite membrane (NCM) is formed with nanostructure and polymer composite membrane (PCM), that could be made with different polymers. It is also important for this discussion because of its functionality as a biodegradable composite membrane that could be made for the conjunction of $\mathrm{NCM}$ and $\mathrm{PCM}^{[17,54]}$.

Biodegradable composite membranes (BCM), especially those based on natural and biodegradable polymers, are widely used in different fields. For a reverse osmosis desalination product $^{[55]}$, prepared a polymeric matrix composed of a membrane doped with fumed silica particles. In the same year $^{[56]}$, developed biodegradable and recyclable cellulose nanofibre composite membranes for use as ultrafiltration (UF) membranes. In addition, Lin et al. ${ }^{[57]}$ developed a biodegradable polyhydroxybutyrate/ poly-e-caprolactone fibrous membrane, modified with a silica composite and hydrolysed for superhydrophobic and outstanding antibacterial applications.

The use of biodegradable polymer from the polyhydroxyalkanoates (PHA) family has been similarly mentioned in all of the research previously cited. For this reason, polyhydroxybutyrate (PHB), which is a natural polymer synthesised by a variety of microorganisms, is commonly used. This polymer is biocompatible, biodegradable and widely studied for medical applications ${ }^{[58,59]}$.

Although PHB shows its hydrophobicity as an advantage, in some cases, its hydrophilicity and crystallinity, which promotes interactions of some materials, could be reached by the functionalisation or addition of other elements (such as nanocellulose or chitosan $)^{[50,60]}$. On the other hand, to improve the PHB performance for bone regeneration in regeneration medicine (RM) and tissue engineering (TE), an alkaline $\mathrm{NaOH}$-based treatment was used and the results showed that rapid, simple, and inexpensive sodium hydroxide treatment modifies the morphology and chemistry of the PHB membrane's nanostructured surface, inducing hydrolysis of ester bonds and creating carboxylic surface functional groups, which increases the surface hydrophilicity ${ }^{[61]}$.

In tissue engineering, a promising use has arisen within regenerative medicine (RM) by considering the context of the biomaterial scaffold made, mainly, by $\mathrm{PHB}^{[62]}$. The antibacterial and antifungal properties of the PHB oligomer proved effective, with some degree of polymerisation. Besides this, the oligomer is also a great candidate for antimicrobial modification in biomedical applications because of its low production cost ${ }^{[63]}$.

The surface modification of PHB, poly (lactic acid) -PLA, poly (methyl methacrylate) -PMMA and polyurethane (PU)/ poly (dimethylsiloxane) (PDMS) films can be accomplished by several techniques and applied to different areas as biodegradable polymers.

The thermal evaporation method ${ }^{[64]}$ for surface modification that occurs by automatic structuring of membranes with fibers, PHB, octadecyl acrylate copolymer and hydrophilic vinylpyrifine of zwitterionics, $\mathrm{zP}$ (4VP-ODA) ${ }^{[60]}$, is a mechanism that is able to control the interactions between fibers and bio-encrustation. In this sense, PHB is a material of interest for bio-scaffolding even though its hydrophobicity generates unwanted interactions with proteins and bacteria, so it is necessary to use an electrospun technique for changing the composite membrane surface with fibers and $\mathrm{PHB}^{[65]}$. In this way, spreading the blend of the membrane surface improved the PHB and fiber hydrophilicity, being able to reduce the serum album adsorption to $92 \%$, lysozyme to $73 \%$ and fibrinogen to $50 \%$. This new composite material is promising for tissue engineering (TE) and other applications in the field, for monitoring environmental sites ${ }^{[66,67]}$. 
As could be verified in the literature cited, PHB has been used in the preparation of membranes for various uses, especially in the healthcare industry ${ }^{[58]}$. One of the most important examples of these uses is the prefabricated stainless-steel masks with different mesh sizes, reinforced with different biodegradable polymers due to surface laser treatment ${ }^{[68]}$. Studies indicate that surface modification can be achieved with a high degree of success and precision ${ }^{[60,69]}$. The surface topographic features created by laser modification appear to improve the binding and growth of human fibroblastic cells in some of the films ${ }^{[68]}$.

Notwithstanding this, regarding the energy and electricity areas, some conductive polymers and nanocomposites have been extensively studied and applied in the field of organic photovoltaic elements and flexible organic electronics. As an example, flexible conductive biopolymer nanocomposites (made with silver nanowires and PHB) have also emerged as a transcutaneous, stimulated sensor ${ }^{[70]}$. This was developed by Tematio et al. ${ }^{[70]}$ in the Laboratory of Applied Nano Sciences at the University of Applied Sciences, Western Switzerland.

Finally, another environmental example was a biopolymer used to produce a nanofiber composite nanofiltration membrane (NCNM) to remove dye from contaminated water. In this research, applied PHB and calcium alginate ${ }^{[7]}$. The membrane pores were formed as nano tubes by using the electrospinning technique. The NCNM (CaAlg-c-PHB/ CNT) was tested to remove dyes with a molecular weight between $400 \mathrm{~g} / \mathrm{mol}$ and $900 \mathrm{~g} / \mathrm{mol}$ and it worked better in a system with high pressure $(0.1 \text { to } 0.7 \mathrm{MPa})^{[72,73]}$.

We sought to explore the research from the last 46 years that dealt with these materials, as well as which countries have published most papers regarding biodegradable tracers for hydrological modelling, identifying emerging pollutants and the ways in which systematic research can inform areas of study that still need to be developed further, regarding new materials and new technologies for the production of biodegradable tracers.

In summary, the main purpose of this section is to explore how environmental tracers (ETS), biodegradable composite membranes (BCM), and functionalised biodegradable polymers (FBP) have been used, especially when applied to environmental monitoring purposes. Furthermore, an overview of the data source, using similar visualisations, will be explained to elucidate how it will be possible to interconnect the ETS, BCM, and FBP with the keywords used to find the papers published and indexed on the Scopus database, relating to the environmental and biodegradable tracers for monitoring surface water and groundwater.

\section{Materials and Methods}

The methodology used in this paper was qualitative and used a bibliographic method for map and cluster development, based on the Visualisation of Similarities (VOS). The free software known as VOS viewer uses the VOS technique. The software is made available by Leiden University for the creation of bibliographic networks. The text mining features allow the building and visualisation of the co-occurrence of networks including the terms extracted from the search results.
This study aims to present a systematic bibliometric literature review of publications (from 1973 to 2020) that present the state of the art of environmental and artificial tracers with low levels of contamination, used for monitoring surface and groundwater. To find these tracers in the publications indexed in the Scopus Database, the bibliometric methodology used was to identify the co-occurrence of nine keywords that could be linked to the production, use, or synthesis of the tracers. The keywords used were: composite membrane, cellulose, silane, microfiltration, nanofiltration, PHB, environmental tracer, membrane, and functionalization. However, these keywords could be combined as a way to better search the database and, because of that, some groups of keywords will appear to showing agglutinated words. The motivation for using these words is because they could reveal the combination of natural and biodegradable products with low cost benefit and high added value that could made innovative tracers.

\subsection{Data sources and visualisation of similarities using the VOS viewer program}

Functional forms to identify similarities in publications related to the same issues are important when determining the status quo of a specific study area. However, when the number of publications, authors, and study year starts to become huge, it is difficult to systematise without a computer tool. Some of these tools were used for a long time by bibliometric and scientometric areas in the library and information sciences ${ }^{[74]}$.

Bibliometrics is a method of associating statistical and econometric laws and principles to map scientific productivity comprising journals, keywords, and authors ${ }^{[75]}$. The laws used are Bradford's Law (to inventory journal productivity), Lotka's Law (to evaluate authors' productivity in the scientific sphere) and Zipf's Law (to locate the frequency of keywords used by researchers $)^{[76]}$.

The tool used to display bibliometric data in an easy and organised way is map projections. These projections can be created by using lines that represent the distances between the items of interest or they can use graphs referencing the items. One of the most-used, open-source tools for visualising bibliometric networks is the VOS viewer software ${ }^{[77,78]}$.

VOS viewer constructs a map based on a co-occurrence matrix system. To start, the VOS viewer needs a similar matrix that will work as an input, relating to associations of linked strength data, as shown in Equation $1^{[79,80]}$.

$$
s i j=\frac{c i j}{(w i * w j)}
$$

Where $s_{i j}$ is the similarity of $i$ and $j$, from the terms inside the matrix system, $c$ means the co-occurrence existing in the same indexes $i$ and $j$, and the weights $w_{i}$ and $w_{i}$ are related to the items correlated in the matrix system ${ }^{[81,82]}$. Then, the maps are created using the VOS layout and the cluster technique. The program has three forms of view: network, overlay, and density. In the network map, the label size and circle size depend on the weight of the author or keywords. The overlay map has the same dynamics as the network map but the items are coloured differently ${ }^{[7,82]}$. 
The main principle of density map identifies items by a label and each one has a colour, depending on the number of items in the vicinity and the importance of neighbouring items ${ }^{[79]}$.VOS viewer also uses the Gaussian kernel function for the density maps, where $\mathrm{k}$ means the dot that will be the product transformed exponentially in the infinite dimension space, and $t$ is the entrance vector data, as shown in Equation $2^{[79]}$.

$$
k(t)=\exp \left(-t^{2}\right)
$$

The other way to see the information could be by cluster density. In this view, all points are calculated separately and, therefore, the density could be calculated using a point $\mathrm{x}$, a cluster $\mathrm{p}$, and a density D by the Equation $3^{[79]}$.

$$
D p(x)=\sum_{i=1}^{n}\left[I_{p}(i) w_{i}\right] K\left(x-x_{i} /\left(\bar{d}_{h}\right)\right.
$$

$\mathrm{Ip}=\mathrm{a}$ function 1 if the item $\mathrm{i}$ belongs to cluster $\mathrm{p}$ but 0 otherwise;

$\mathrm{K}=$ Gaussian kernel function.

As a result, all clusters calculated will receive a color that's depend on the total item density of a point ${ }^{[83]}$.

For the research in this database $\mathrm{e}^{[84]}$, the strategy of using the nine keywords cited above could be viewed in Figure 1 . combined in seven groups, always based on the three words retained out of the nine chosen. In the first six groups, PHB and membrane were fixed and a word was added. The seventh group worked with environmental tracer and membrane.

In the research, the "AND" connector was used to bring results that included all terms according to the constructed groups. Thus, it was possible to obtain global results, allowing a comprehensive view of the topic of interest. The search found 203 publications related to the seven groups. Then, the results were downloaded in the Research Information Systems (.ris), which is the file format used to transfer and store bibliographic citation data.

The file in ".ris" with the final version, was extracted from Mendeley and uploaded to VOS viewer to create the bibliometric network that identifies the recurrence of the most common terms in this research. A network was created, following the settings within the software: the option to create a map based on bibliographic data was selected. The type of analysis was co-occurrence and co-authorship (the relationship between items is determined by the number of documents in which they occur together). The units of analysis were keywords and authors. The counting method was fractioned, where the weight of each co-authorship or co-occurrence link is fractioned, and ultimately, the minimum number of occurrences of keywords chosen for the search was three.

Windows 10, Excel ${ }^{\circledR}$ and SAS $\AA$ software were also used to analyse the data such as years of publication, papers, publication by country and groupings by keywords.

\section{Results and Discussions}

\subsection{The scenario of artificial and natural tracers' publications per year}

The result of the five decades of publications presented in this paper picked up the scenario of artificial and natural tracers for monitoring the aquatic environment. The beginning of the studies of natural tracers was in 1973, in the medicine field in Germany. The study was related to phosphate transfer through natural membranes, as measured by tracer exchange properties ${ }^{[85]}$.

Firstly, in this research, it was possible to infer that there was an ascending number of publications related to the nine keywords used in this research (see Figure 2). Secondly, it was possible to figure out that in two decades, between the 1990s and 2000s, there was a significant growth rate related to the sustainable approach all over the world.

In the year 2000 in Mexico, groundwater flow was monitored downfield from wastewater systems using artificial tracer techniques on St. George Island, located in the North-East Gulf of Mexico ${ }^{[86]}$. In the 1990s, research about artificial tracer tests contributed to the knowledge of the transfer time for a pollutant between the inlets and the outlets ${ }^{[87]}$.

Figure 2 also indicates that there is a crescent tendency of the number of publications in the years 1997 to 2002 and

\begin{tabular}{|c|c|c|}
\hline \multicolumn{3}{|c|}{ Groun 1} \\
\hline PHB & Membrane & Cellulose \\
\hline \multicolumn{3}{|c|}{4} \\
\hline \multicolumn{3}{|c|}{ Groum 2} \\
\hline PHB & Membrane & Silane \\
\hline \multicolumn{3}{|c|}{ Sy } \\
\hline \multicolumn{3}{|c|}{ Gromm 3} \\
\hline PHB & Membrane & Nanofiltration \\
\hline \multicolumn{3}{|c|}{$8 \zeta$} \\
\hline \multicolumn{3}{|c|}{ Group 4} \\
\hline PHB & Membrane & Microfiltration \\
\hline \multicolumn{3}{|c|}{ V } \\
\hline \multicolumn{3}{|c|}{ Groum 5} \\
\hline $\mathrm{PHB}$ & Membrane & Functionalization \\
\hline \multicolumn{3}{|c|}{5} \\
\hline \multicolumn{3}{|c|}{ Croum 6} \\
\hline PHB & Membrane & Composite \\
\hline \multicolumn{3}{|c|}{ 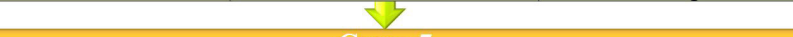 } \\
\hline \multicolumn{3}{|c|}{ Groun 7} \\
\hline Environmental & Tracer & Membrane \\
\hline
\end{tabular}
2002 to 2008 . This was probably related to the concept of

Figure 1. The seven groups encompassing the keywords searched using the Scopus databased. 
sustainable development which was represented by some important international conferences such as Rio-92 and the Ministerial Conference of Environmenta ${ }^{[88]}$. In the following decade, the Agenda 21 and Millennium Development Goals (MDG) international events constituted an exciting emerging area regarding responsible consumers and sustainable development ${ }^{[89]}$.

Even with the annual growth, statistical data analyses show there is still a lag concerning the subject, with the number of papers published annually from 1990 to 2000 being incipient, which totals no more than 3.3 per year in a decade of global publication. In the following decade, even with the tripling of the annual average of publications, it was still not possible to reach 10 publications per year, which shows relevant but not high enough annual growth. Moreover, most of the publications do not mention any information about the approach to decrease environmental risks related to the permanence of artificial tracers in the environment.
Following the potential and exponential growth of contaminated aquatic areas, the growth of the research concerning environmental tracers does not follow the trends. The papers presented in the indexed journals in Scopus databases still work with old types of artificial tracers like radioactive or color tracers, as shown by Hillebrand et al. ${ }^{[90]}$ and Zhang et al. ${ }^{[1]}$.

\subsection{Distribution by journals, publications, and country to identify the tendencies}

The journals database and the number of publications that used the nine keywords chosen for this paper over the last 47 years, found 94 journals published in different areas and subjects of study. For the most part, the average journal publication was 2 , which represented only $8 \%$ of the total annual publication in those journals.

Alternatively, Figure 3 shows the main 12 journals with more publications. These journals use an impact

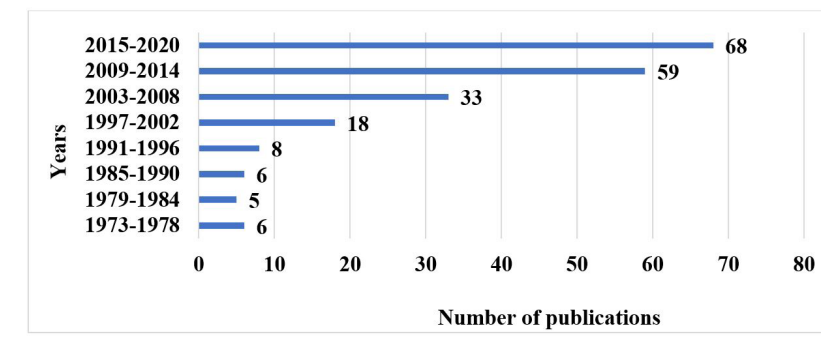

\begin{tabular}{ccccccccccc}
\hline \multirow{2}{*}{$\begin{array}{c}\text { Periods } \\
\end{array}$} & $2015-$ & $2004-$ & $2003-$ & $1997-$ & $1991-$ & $1985-$ & $1979-$ & $1973-$ \\
& $\mathbf{2 0 2 0}$ & $\mathbf{2 0 1 4}$ & $\mathbf{2 0 0 8}$ & $\mathbf{2 0 0 2}$ & $\mathbf{1 9 9 6}$ & $\mathbf{1 9 9 0}$ & $\mathbf{1 9 8 4}$ & $\mathbf{1 9 7 8}$ \\
$\begin{array}{c}\text { Mean numbers of } \\
\text { publications }\end{array}$ & 12.33 & 9.83 & 5.50 & 3.00 & 1.33 & 1.00 & 0.83 & 1.00 \\
\hline
\end{tabular}

Figure 2. Number of publications from 1973 to February 2020, using the keywords: PHB, membrane, cellulose, silane, nanofiltration, microfiltration, functionalization, membrane composite and environmental tracer, and Mean number of publications for every six year.

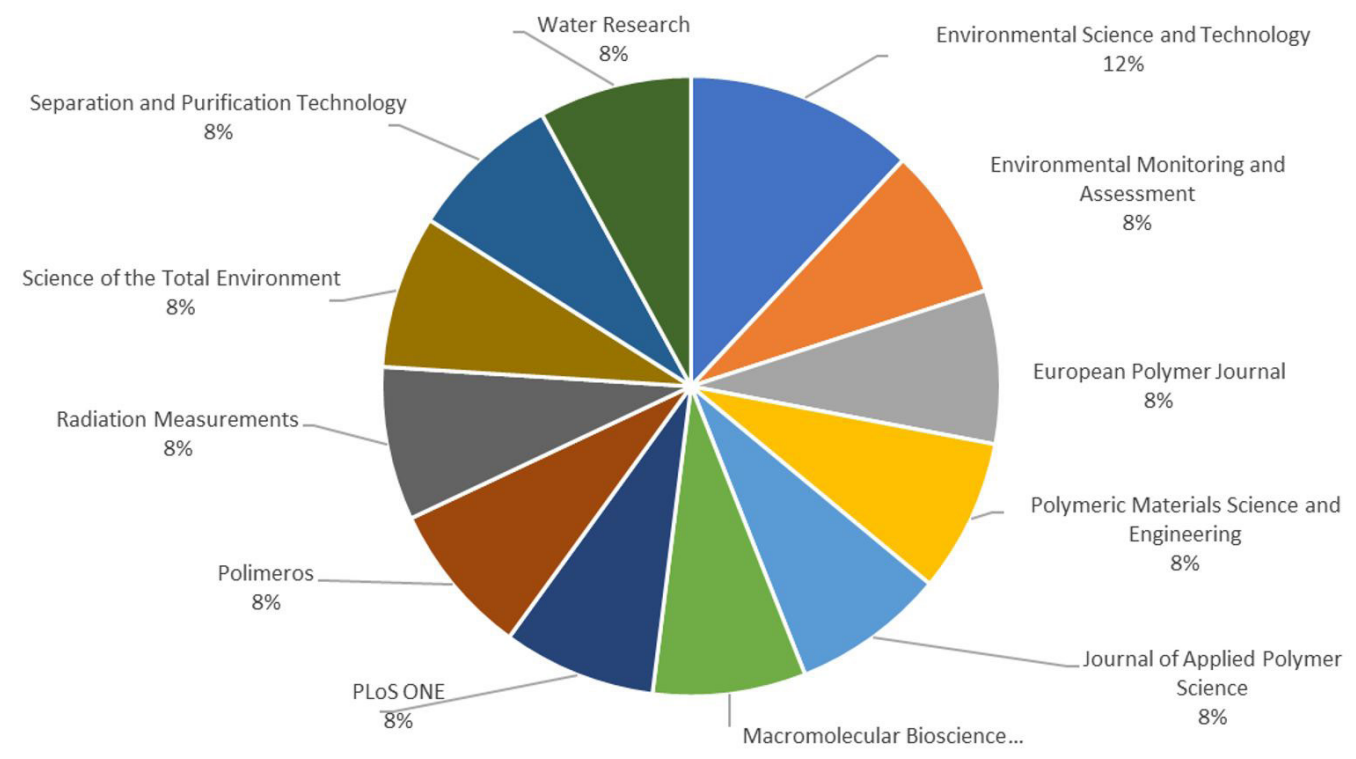

Figure 3. Journals with the most papers published (from 1973 to 2020) that used the keywords research. 
factor as an index of quality and they have the 3 highest impact factors in the environmental field in 2019. i.e. Water Research Journal $(9,130)$, the Environmental Science and Technology $(7,864)$ and Science of the Total Environment $(6,551)$. The other journals also use impact factor and none of them have impact factors below $1.0^{[92]}$.

The remaining 82 journals were completely spread among all over the world in areas such as medicine, biology, microbiology, chemistry, physics, the environment, water, veterinary medicine, polymeric materials, oil, and energy. The Environmental Science and Technology journal represented most of the publications.

An examination of the findings of the results shown in Figure 4 provides relevant information about the countries that lead research outputs, by groups of keywords and by study area. The first country with the most publications regarding environmental tracers is the United States of America (28.12\%), the second is Germany (14.06\%) and the third, France (10.16\%). However, the country with the most publications on biodegradable materials, that could be used for biodegradable tracers, is China (31.95\%), followed by Brazil (14.28\%) and Germany (11.90\%).

Concerning microfiltration and nanofiltration membranes using the PHB, the ranking of the countries is led by China $(77.77 \%)$ and then France and Malaysia, with the same proportion (11.11\%). Furthermore, the general ranking concerning publications by country showed that the countries with the highest research numbers in the summary area (within all nine keywords used) are the United States, China, Germany, and France.

It may be inferred that the ranking is linked to investment in research and development (R\&D). Since 2000, the USA, Germany, the United Kingdom, China, and France have been among the twenty countries that have invested the most in $\mathrm{R} \& \mathrm{D}$, according to OECD data ${ }^{[4] 1}$.

The USA has been targeting more than $2.6 \%$ since 2000 and has remained almost constant over time. In the same year, Germany invested more than $2.4 \%$ and this percentage went up to $3.1 \%$ in 2018 . China had an increase in its investment, going from $0.9 \%$ in 2000 to $2.1 \%$ in 2018 . France has remained at around $2.1 \%$ and the United Kingdom invested $1.61 \%$ in 2000 and had a 9\% increase in $2018^{[93]}$.

These countries concentrated their important research in Universities and Research Centres, as shown in Table 1. This presents the distribution of the papers by affiliation and the countries in which they were published. Most of the publications were conducted by the two or three main universities in the country with the referenced research areas. There are some exceptions, e.g. the University of Wrocław in Poland and the University of Rouen in France.

To sum up, there are four countries and eleven universities in three continents putting effort into these areas of study. They have been responsible for $68.07 \%$ of all publications in the last 47 years, with an average of 2.35 papers published per year (less than one paper per continent per year). Using this information, it is possible to infer that there is a gap in publications in this field.

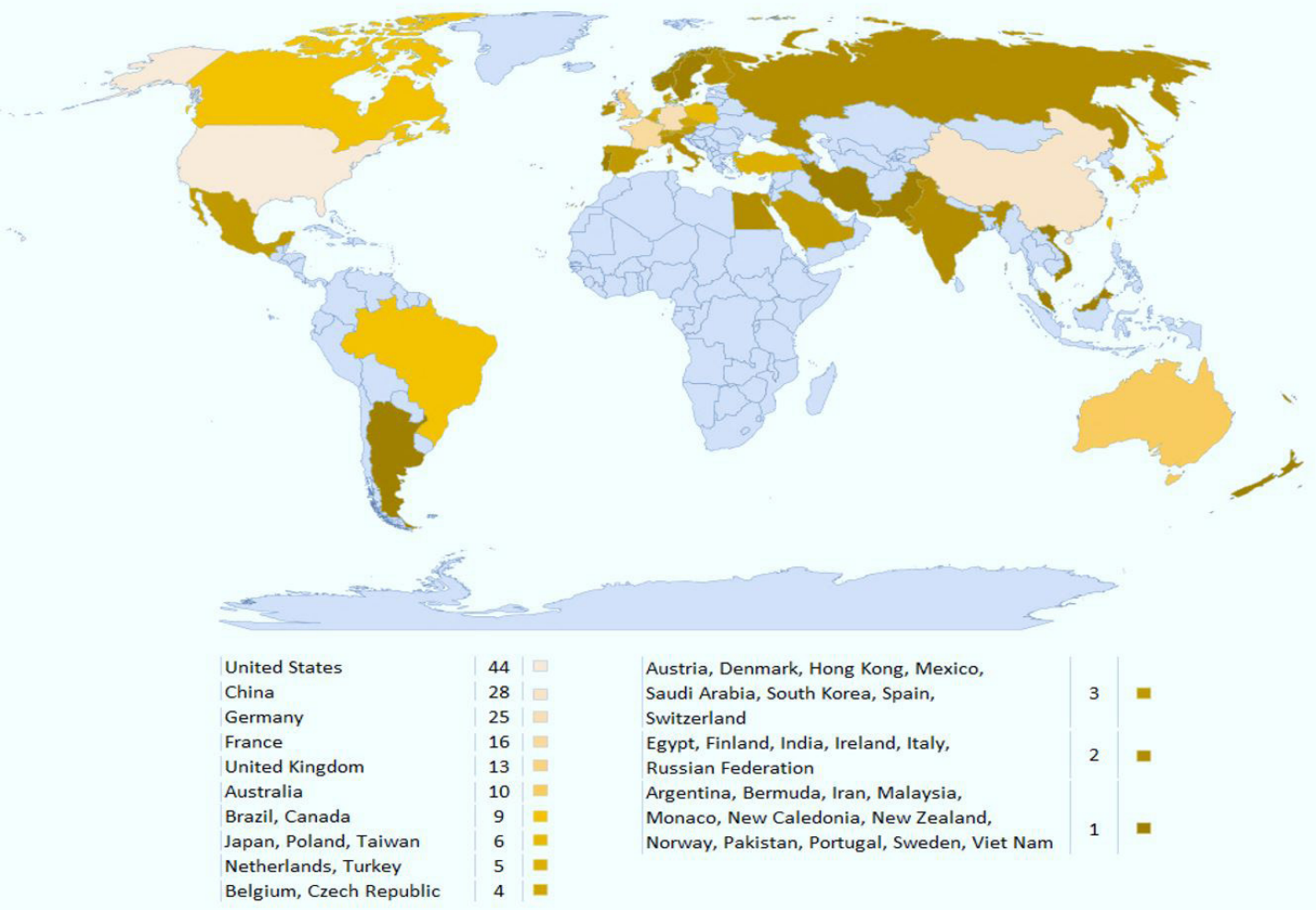

Figure 4. The world map with the number of publications by country, relating to groups of three keywords (PHB, membrane, cellulose, silane, nanofiltration, microfiltration, functionalisation, and environmental tracer) using the Scopus Database. 


\subsection{Author and co-authorship}

The relationship between the authors and co-authorship was visualized by VOS viewer because of our study, there are 798 authors involved in at least one paper with co-authorship. This presents 52 clusters in an overlay visualization. In the next scenario (Figure 5), the arrangement was defined by two conditions: firstly, that each author must have 3 papers published and, secondly, there should be a connection between them.

The way that was chosen to show the clusters was 'overlay visualization' and, because of that, Figure 5 shows all of the clusters, with a stronger linkage among them. This type of data is important because it shows an overview of all authors. On the other hand, some of the authors seen in Figure 5 will disappear if the connection is narrowed, and sometimes important information is lost.

When the clusters are narrowed or when there are too many restrictions, this results in Figure 6.
The three researchers with the most publications and co-authorship appear with the highest circle in the clusters shown in Figure 6. These researchers are described below. Zhijian Cai (an associate professor and Ph.D. supervisor at Tianjin University) works with nanofiltration membranes and PHB. Fei Liu (a professor in the Key Laboratory of Water Resources and Environmental Engineering and works with the groundwater monitoring system); some of his research has studied artificial tracers for monitoring groundwater and considered the presence of emerging contaminants, in his publishing group. Ziheng Zhang (from the Research Centre for Smart Wearable Technology at the Institute of Textile and Clothing) who works with PHB and its blends, showing studies based on the kinetic and mechanical properties of these blends.

The identification of authors separated by affiliation and country is shown in Figure 6 and the clusters are separated by main authors and co-authors. The results indicate the

Table 1. Distribution of the intellectual production by affiliation and country.

\begin{tabular}{ccc}
\hline Related clusters & Affiliation & Country \\
\hline 5 & State Key Laboratory of Separation Membranes and Membrane Processes, School of Textiles, Tianjin & China \\
& Polytechnic University, & China \\
5 & Key Laboratory of Eco-textiles of Ministry of Education, College of Textiles & China \\
3 & Jiangsu Engineering Technology Research Center for Functional Textiles & China \\
5 & School of Material Science and Engineering, Tianjin Polytechnic University & China \\
6 & School of Textiles, Tianjin Polytechnic University, Tianjin & France \\
2 & Department of Biology, University of Rouen & Germany \\
2 & Technical University of Dresden & Germany \\
2 & Ernst Moritz Arndt University of Greifswald & Poland \\
2 & Silesian Piast Medical Academy Wroclaw & Poland \\
2 & University in Wrocław & Russia \\
1 & Academia Médica Estadual de Nizhny Novgorod & Russia \\
3 & University of Moscow & USA \\
3 & Department of Poultry Science, Auburn & USA \\
6 & Department of Chemistry, University of Massachusetts, Lowel & USA \\
\hline
\end{tabular}

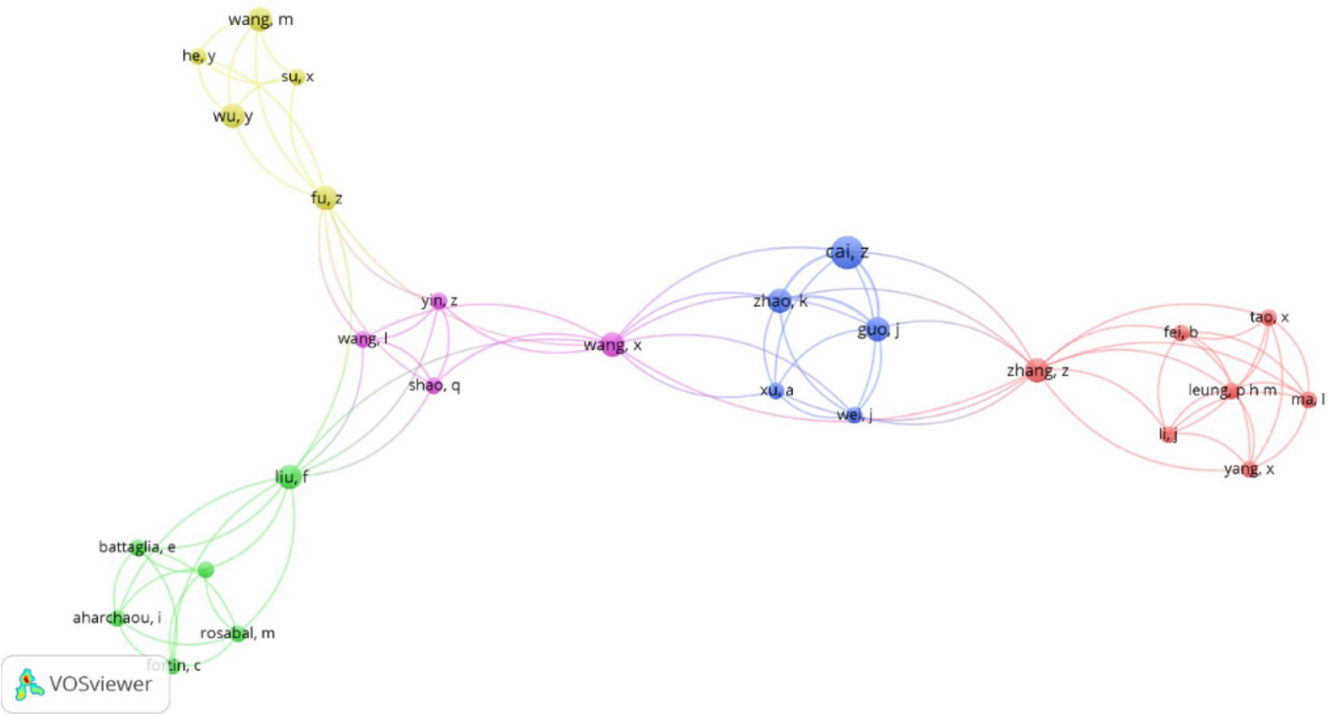

Figure 5. Clusters with authors that have 3 papers or more and with a linkage between them. 
existence of 6 clusters. Figure $6 \mathrm{~b}$ identifies how the cluster appears in the VOS viewer programme and how the author and authorship could be studied by their linked strength correlation. Figure 6a shows the groups of authors.

Cluster 1 is from the research group at Moscow University and its main research concerns poly(3-hydroxybutyrate) and polymer film production ${ }^{[94]}$. In cluster 2 , the main research objectives are biocomposites made by flax fibres for testing the proliferation of bacteria ${ }^{[95]}$. Cluster 3 shows the authors and co-authors that research composite hydrogels reinforced by cellulose ${ }^{[96]}$. Cluster 4 researches polymers and Cluster 5 shows the authors that research in the field of membrane and filtration systems ${ }^{[4]}$. Artificial and natural tracers are the main field of research for Cluster $6^{[86]}$

\subsection{Keywords and co-occurrence scenarios}

By using keywords as the unit of analysis with the full counting method, the chosen threshold found 3,148 keywords with a minimum of 5 occurrences. The network visualisation per occurrence and co-occurrence indicates that there are four clusters, as presented in Figure 7 and 8. The first deals with the use of membranes in sewage treatment plant bioreactors. The second cluster talks about groundwater and environmental monitoring, traditionally performed with conventional tracers.

The third cluster refers to the use of polymers, such as PHB, composite membranes, and artificial membranes, and their use in areas such as medicine and biology (in terms

(a)

\section{CLUSTER 1}

ANDREEVA, NV

BONARTSEV, AP BONARTSEVA, GA MYSHKIMA, VL ZERNOV, AL ZHARKOVA, II

(b)

CLUSTER 2
DOMINIAK, M
GEDRANGE, T
GREDES, T
KUNERT-KEIL, C
WROBEL-KWIATKOWSKA, M

CLUSTER 3

$\begin{array}{llll}\text { HUANG, TS } & \text { CLUSTER 4 } & \text { CLUSTER 5 } & \\ \text { LI, L } & \text { CONG, Z } & \text { CAI, Z } & \\ \text { LIN, X } & \text { JIE, G } & \text { GUO, J } & \text { CLUSTER 6 } \\ \text { REN, X } & \text { KONGYIN, Z } & \text { ZHANG, Z } & \text { NORRIS, V } \\ \text { SUN, Y } & \text { ZHIJANG, C } & \text { ZHAO, K } & \text { REUSCH, RN }\end{array}$

SUN, Y
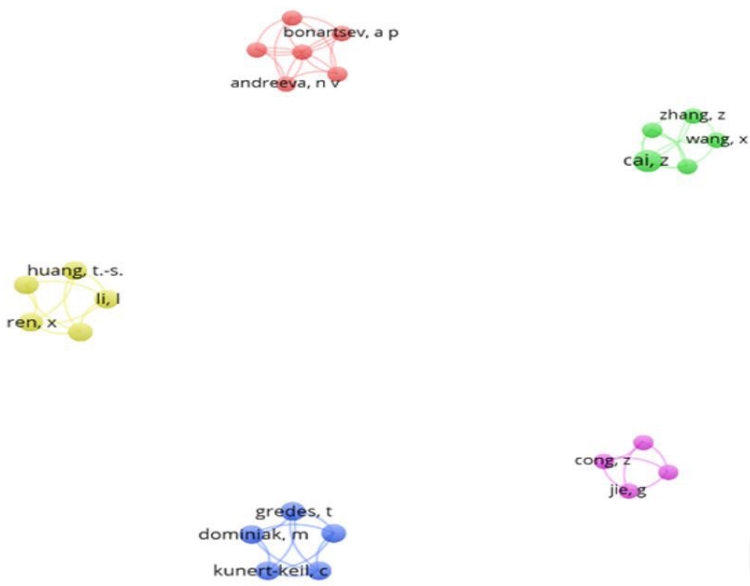

reusch, $r n$

\& Vosviewer

Figure 6. Authors and co-authors linked with the highest total linked strength by publications (a) list of author and co-authorship related to affiliation on Table 2; (b) network visualisation of clusters by authors and co-authorship.

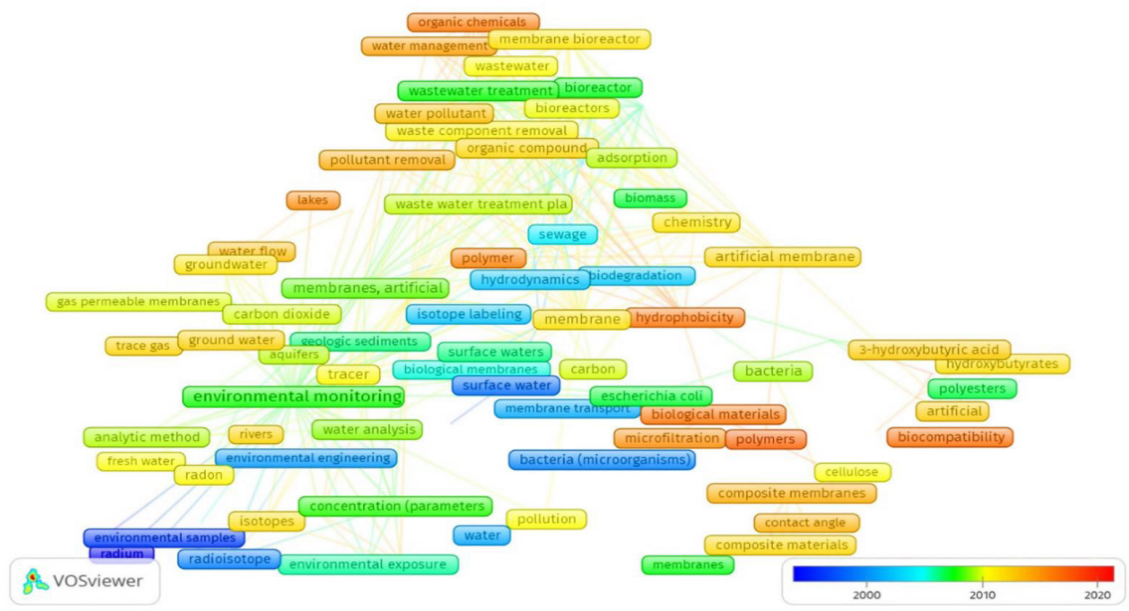

Figure 7. Overview visualisation on time-based trends in academic studies from 1995 to 2020. 


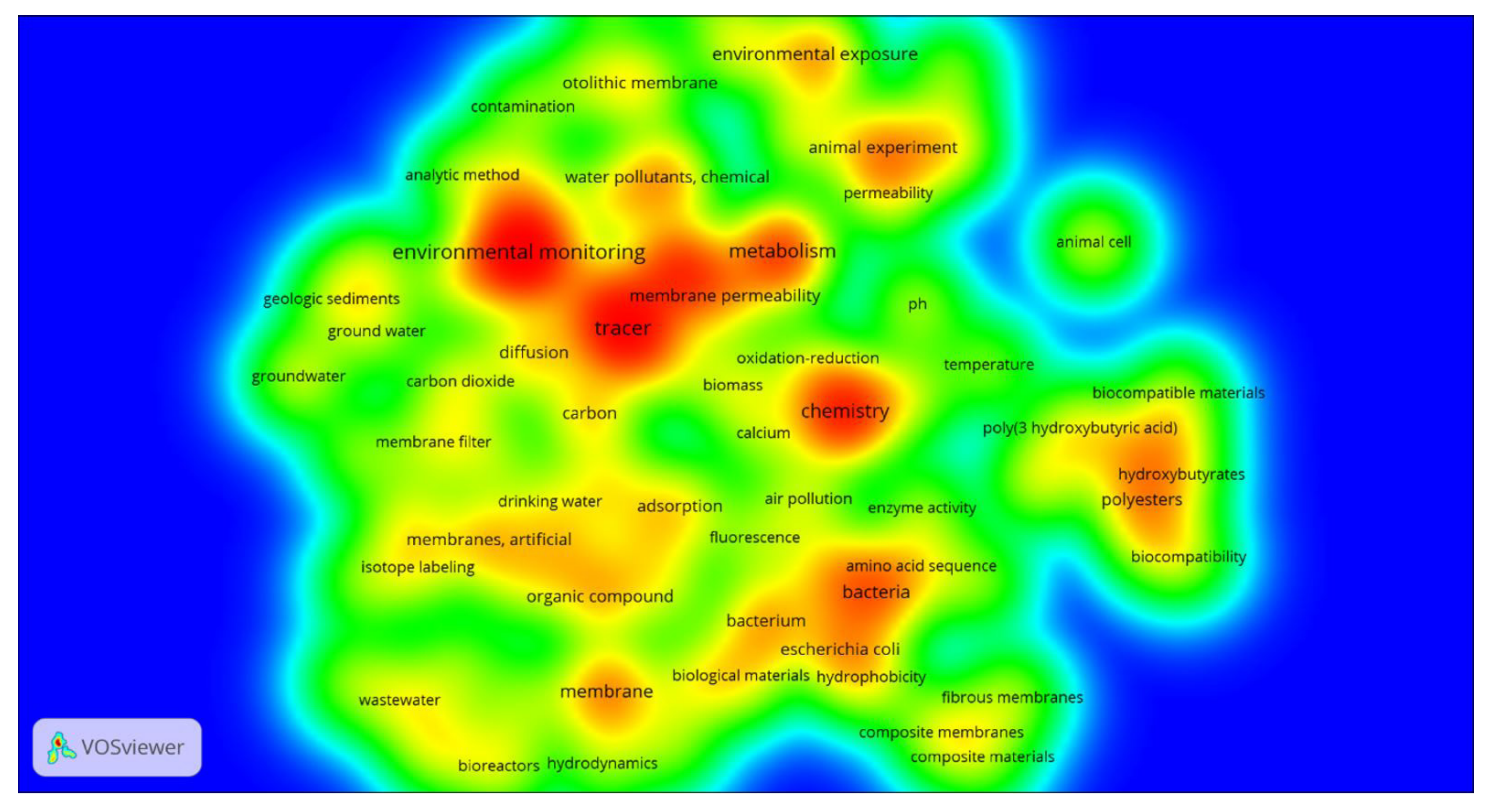

Figure 8. Occurrence of keywords during the years of investigation, from 1973 to 2020.

Table 2. The relations between keywords and their occurrence; a linked strength of the Top 10.

\begin{tabular}{ccc}
\hline Keyword & Occurrence & Total linked strength \\
\hline Membrane/artificial membrane/ Composite membranes & 33 & 181 \\
Water pollutant/ Wastewater treatment plant (WWTP)/ sewage & 29 & 290 \\
Environmental monitoring/ water monitoring & 27 & 163 \\
Tracer: radioisotope/ environmental & 18 & 128 \\
PHB/ polymer & 11 & 30 \\
Unclassified drugs & 9 & 73 \\
Bioreactor & 7 & 45 \\
Biodegradation & 6 & 104 \\
Groundwater & 6 & 36 \\
Cellulose/nanocellulose & 3 & 10 \\
\hline
\end{tabular}

of biocompatibility). The fourth cluster deals with water pollution by chemicals, their concentrations, occurrences, and bioaccumulation problems in humans and the high loads present in nature.

From 2010, the research continued in the environmental area, incorporating the medicine area to better develop the issue of biocompatibility of biopolymers and membranes with drugs and, therefore, possibilities for improvement and effectiveness in the quality of human life.

At the same time, the words 'fibre-reinforced membranes', 'adsorption', 'hydrophobicity', 'biodegradable polymers', and 'tracers' are present in several papers concerning sewage, groundwater and surface water treatment. Nonetheless, the major concern that motivated and directed the research was the need to improve the quality of environmental monitoring so that prior knowledge of a possible problem could be mitigated before more expense was needed to solve $i^{[59,95]}$.

Under different circumstances and by analyzing the specific keywords directly related to the words that were researched, but from a temporal point of view, it is possible to determine that, by 2010, research in the area of biodegradable polymers using $\mathrm{PHB}$, membranes, tracers, and cellulose was focused on the analysis of environmental issues using tracers as a tool (isotopes) in surface and groundwater, as shown in Table 2.

Also, regarding the use of membranes, most of the publications were concerned with the implantation of filters and reactors in water and wastewater treatment plants. However, the most important information in Table 2 is the relationship between linked keywords and their occurrence in the papers. Correlation between the published articles can be made by assigning values to the relationship between the repeated keywords inside them ${ }^{[81]}$.

This correlation is identified and quantified in the VOSviewer program, according to its manual, using numerical values referring to the strength of the keywords ${ }^{[97]}$. This binding force is linked to the number of occurrences and the highest value gives the strongest link. Table 2 shows the top 10 keywords which gave the highest value of linked strength in the research ${ }^{[82]}$.

Numbered lists can be added a Finally, Table 3 presents a scatter plot for each group of relevant words by country. This information gives a quick view about the preferences of publications by country and shows the tendencies of academic research works. China is a unique country that works in all fields mentioned in the Table 3 and also has 
Table 3. Word group by publication and country.

\begin{tabular}{|c|c|c|c|c|c|c|c|c|}
\hline \multirow{2}{*}{ Country } & \multirow{2}{*}{ TP } & \multicolumn{7}{|c|}{ Word Group (WG) } \\
\hline & & ETS & РСМ & PMS & PMN & PMM & PMF & PMC \\
\hline United States of America & 44 & 35 & - & 1 & - & - & 5 & 3 \\
\hline China & 28 & 7 & 1 & 2 & 3 & 4 & 1 & 10 \\
\hline Germany & 25 & 18 & 2 & - & - & - & 2 & 3 \\
\hline France & 16 & 13 & - & - & - & 1 & 2 & - \\
\hline United Kingdom & 13 & 13 & - & - & - & - & - & - \\
\hline Australia & 10 & 9 & - & - & - & - & - & 1 \\
\hline Brazil & 9 & 2 & 2 & - & - & - & 1 & 4 \\
\hline Canada & 9 & 7 & - & - & - & - & 2 & - \\
\hline Japan & 6 & 5 & - & - & - & - & 1 & - \\
\hline Poland & 6 & 1 & - & - & - & - & 2 & 3 \\
\hline Taiwan & 6 & 2 & - & - & - & - & 3 & 1 \\
\hline Netherlands & 5 & 4 & - & - & - & - & - & 1 \\
\hline Turkey & 5 & 1 & & - & - & - & 3 & 1 \\
\hline
\end{tabular}

TP: total publication; ETS: environmental tracers - membrane; PCM: Polymer and Composite Membrane; PMS: Polymer, membrane, and Silane; PMN: Polymer, membrane and nanofiltration; PMM: polymer membrane, and microfiltration; PMF: Polymer, membrane and functionalization; PMC: Polymer membrane cellulose.

the highest publication in the field of PCM (10) followed by Brazil (4), Germany, and Poland (3).

The United States of America has most of the publications on the monitoring of surface water and groundwater using environmental tracers - ETS (35) followed by Germany (18), France and the United Kingdom (13). Moreover, none of the countries used biodegradable tracers. Most of the tracers used were colored, isotopic or luminescent tracers. The data also showed that the minority of publications are in the field of polymeric membranes, functionalized with silanes and nanofiltration polymeric membranes.

In addition to making large financial investments, these countries have funding institutions for research and development: in China, it is the National Foundation for Natural Sciences; in Europe, it is the European Commission and, in the United States, it is the National Science Foundation. All of these investments create returns for the countries involved, and it is worth noting that these are the countries with the greatest economic growth in recent years, being in the G20 group and with the largest investment of GDP in $\mathrm{R} \& \mathrm{D}$ in the world ${ }^{[98]}$.

\section{Conclusions}

Undoubtedly, in times of great challenges and socioeconomic and environmental risks, there is a need for academic research to be ahead of the times. The need for quick and direct responses to new threats of contamination of the water, soil and the global population itself raises the question of planning and directing academic research.

This paper provides a bibliometric investigation of research on a biodegradable tracers for monitoring surface water and groundwater, from 1973 to February. The research findings gave three important answers. Firstly, in the last 47 years, tracers have been used in different ways and for different purposes in medicine, agriculture, and hydrological engineering. Secondly, most of the tracers used worldwide are either radioisotope, fluorescent, or chemical, and all of them leave a residue of contaminants in the aquatic environment after being used.
Environmental concerns have increased over the past 20 years, notwithstanding the fact that the artificial tracers that have been developed still carry a large polluting load and there has been no new research for biodegradable tracers with low ecotoxicity for environmental sites. According to the prior study, artificial tracers made with biodegradable materials with low toxicity should be an important research area for the future.

\section{Acknowledgements}

The authors would like to thank CAPES (Coordenação de Aperfeiçoamento de Pessoal de Nível Superior), DPG/ UnB (Decanato de Pós Graduação/ University of Brasília), FAPDF (Fundação de Apoio à Pesquisa do Distrito Federal) and $\mathrm{CNPq}$ (Conselho Nacional de Desenvolvimento Científico e Tecnológico) for their financial support to this Project.

\section{References}

1. Barzegar, R., Moghaddam, A. A., Deo, R., Fijani, E., \& Tziritis, E. (2018). Mapping groundwater contamination risk of multiple aquifers using multi-model ensemble of machine learning algorithms. The Science of the Total Environment, 621, 697-712. http://dx.doi.org/10.1016/j.scitotenv.2017.11.185. PMid:29197289.

2. Kaboré, H. A., Vo Duy, S., Munoz, G., Méité, L., Desrosiers, M., Liu, J., Sory, T. K., \& Sauvé, S. (2018). Worldwide drinking water occurrence and levels of newly-identified perfluoroalkyl and polyfluoroalkyl substances. The Science of the Total Environment, 616-617, 1089-1100. http://dx.doi. org/10.1016/j.scitotenv.2017.10.210. PMid:29100694.

3. Wei, C., Wang, Q., Song, X., Chen, X., Fan, R., Ding, D., \& Liu, Y. (2018). Distribution, source identification and health risk assessment of PFASs and two PFOS alternatives in groundwater from non-industrial areas. Ecotoxicology and Environmental Safety, 152, 141-150. http://dx.doi.org/10.1016/j. ecoenv.2018.01.039. PMid:29402442.

4. Sultana, T., Murray, C., Ehsanul Hoque, M., \& Metcalfe, C. D. (2017). Monitoring contaminants of emerging concern from tertiary wastewater treatment plants using passive sampling modelled with performance reference compounds. 
Environmental Monitoring and Assessment, 189(1), 1. http:// dx.doi.org/10.1007/s10661-016-5706-4. PMid:27909849.

5. Andrade, L., O’Dwyer, J., O’Neill, E., \& Hynds, P. (2018). Surface water flooding, groundwater contamination, and enteric disease in developed countries: a scoping review of connections and consequences. Environmental Pollution, 236, 540-549. http://dx.doi.org/10.1016/j.envpol.2018.01.104. PMid:29428708.

6. Erdal, D., \& Cirpka, O. A. (2017). Preconditioning an ensemble Kalman filter for groundwater flow using environmental-tracer observations. Journal of Hydrology, 545, 42-54. http://dx.doi. org/10.1016/j.jhydrol.2016.11.064.

7. Battaglia, D., Birindelli, F., Rinaldi, M., Vettraino, E., \& Bezzi, A. (2016). Fluorescent tracer tests for detection of dam leakages: the case of the Bumbuna dam - Sierra Leone. Engineering Geology, 205, 30-39. http://dx.doi.org/10.1016/j. enggeo.2016.02.010.

8. Long, A. J., Sawyer, J. F., \& Putnam, L. D. (2008). Environmental tracers as indicators of karst conduits in groundwater in South Dakota, USA. Hydrogeology Journal, 16(2), 263-280. http:// dx.doi.org/10.1007/s10040-007-0232-7.

9. Mahler, B., \& Massei, N. (2007). Anthropogenic contaminants as tracers in an urbanizing karst aquifer. Journal of Contaminant Hydrology, 91(1-2), 81-106. http://dx.doi.org/10.1016/j. jconhyd.2006.08.010. PMid:17161500.

10. Näslund, O., Smits, A., Förander, P., Laesser, M., Bartek, J., Jr., Gempt, J., Liljegren, A., Daxberg, E. L., \& Jakola, A. S. (2018). Amino acid tracers in PET imaging of diffuse low-grade gliomas: a systematic review of preoperative applications. Acta Neurochirurgica, 160(7), 1451. http://dx.doi.org/10.1007/ s00701-018-3563-3. PMid:29797098.

11. Boester, U., \& Rüde, T. R. (2020). Utilize gadolinium as environmental tracer for surface water-groundwater interaction in Karst. Journal of Contaminant Hydrology, 235, 103710. http:// dx.doi.org/10.1016/j.jconhyd.2020.103710. PMid:33125978.

12. Silva, L. L., Donnici, C. L., Ayala, J. D., Freitas, C. H., Moreira, R. M., \& Pinto, A. M. F. (2009). Traçadores: o uso de agentes químicos para estudos hidrológicos, ambientais, petroquímicos e biológicos. Química Nova, 32(6), 1576-1585. http://dx.doi. org/10.1590/S0100-40422009000600042.

13. Van der Schyff, M., Kanyerere, T., Israel, S., \& Vermaak, N. (2020). Using multiple tracers and geological techniques to determine the connectivity between aquifer systems, West Coast, South Africa. Physics and Chemistry of the Earth, 118-119, 102863. http://dx.doi.org/10.1016/j.pce.2020.102863.

14. Ribeiro, G. L., Dausacker Bidone, E., Melo, M. A., \& Gonzalez da Silva, I. P. (2016). Traçadores hidrossolúveis para caracterização de reservatórios de petróleo. Engevista, 18(1), 23-42. http://dx.doi.org/10.22409/engevista.v18i1.679.

15. Chambers, L. A., Gooddy, D. C., \& Binley, A. M. (2019). Use and application of CFC-11, CFC-12, CFC-113 and SF6 as environmental tracers of groundwater residence time: a review. Geoscience Frontiers, 10(5), 1643-1652. http://dx.doi. org/10.1016/j.gsf.2018.02.017.

16. Clémence, H., Marc, P., Véronique, D., \& Toihir, A. (2017). Monitoring an artificial tracer test within streambed sediments with time lapse underwater 3D ERT. Journal of Applied Geophysics, 139, 158-169. http://dx.doi.org/10.1016/j. jappgeo.2017.02.003.

17. Darling, W. G., Gooddy, D. C., Riches, J., \& Wallis, I. (2010). Using environmental tracers to assess the extent of rivergroundwater interaction in a quarried area of the English Chalk. Applied Geochemistry, 25(7), 923-932. http://dx.doi. org/10.1016/j.apgeochem.2010.01.019.

18. Pavlovskiy, I., \& Selle, B. (2015). Integrating hydrogeochemical, hydrogeological, and environmental tracer data to understand groundwater flow for a karstified aquifer system. Ground Water, 53(Suppl. 1), 156-165. http://dx.doi.org/10.1111/gwat.12262. PMid:25178951.

19. Zoellmann, K., Kinzelbach, W., \& Fulda, C. (2001). Environmental tracer transport ( $3 \mathrm{H}$ and $\mathrm{SF} 6)$ in the saturated and unsaturated zones and its use in nitrate pollution management. Journal of Hydrology, 240(3-4), 187-205. http://dx.doi.org/10.1016/ S0022-1694(00)00326-7.

20. Einsiedl, F. (2005). Flow system dynamics and water storage of a fissured-porous karst aquifer characterized by artificial and environmental tracers. Journal of Hydrology, 312(1-4), 312-321. http://dx.doi.org/10.1016/j.jhydrol.2005.03.031.

21. Labat, D., \& Mangin, A. (2015). Transfer function approach for artificial tracer test interpretation in karstic systems. Journal of Hydrology, 529, 866-871. http://dx.doi.org/10.1016/j. jhydrol.2015.09.011.

22. Heiß, L., Bouchaou, L., Tadoumant, S., \& Reichert, B. (2020). Multi-tracer approach for assessing complex aquifer systems under arid climate: case study of the River Tata catchment in the Moroccan Anti-Atlas Mountains. Applied Geochemistry, 120, 104671. http://dx.doi.org/10.1016/j.apgeochem.2020.104671.

23. Schubert, M., Brueggemann, L., Knoeller, K., \& Schirmer, M. (2011). Using radon as an environmental tracer for estimating groundwater flow velocities in single-well tests. Water Resources Research, 47(3), 1-8. http://dx.doi.org/10.1029/2010WR009572.

24. Heilweil, V. M., Sweetkind, D. S., \& Gerner, S. J. (2014). Innovative environmental tracer techniques for evaluating sources of spring discharge from a carbonate aquifer bisected by a river. Ground Water, 52(1), 71-83. http://dx.doi.org/10.1111/ gwat.12030. PMid:23425448.

25. Carlo, L., Alessandra, B., Dario, S., Mauro, C., Gianfranco, G., Michele, S., \& Paola, T. (2019). Testing the radon-inwater probe set-up for the measurement of radon in water bodies. Radiation Measurements, 128, 106179. http://dx.doi. org/10.1016/j.radmeas.2019.106179.

26. Sanford, W., Anderholm, S., Busenberg, E., Bexfield, L., \& Plummer, L. N. (2004). Hydrochemical tracers in the middle Rio Grande Basin, USA: 1. Conceptualization of groundwater flow. Hydrogeology Journal, 12(4). http://dx.doi.org/10.1007/ s10040-004-0326-4.

27. Irrgeher, J., \& Prohaska, T. (2016). Application of non-traditional stable isotopes in analytical ecogeochemistry assessed by MC ICP-MS: a critical review. Analytical and Bioanalytical Chemistry, 408(2), 369-385. http://dx.doi.org/10.1007/s00216015-9025-3. PMid:26446900.

28. Purdy, R. N., Dancer, B. N., Day, M. J., \& Stickler, D. J. (1986). Bacillus phages as tracers of water movement. Water Science and Technology, 18(4-5), 149-153. http://dx.doi.org/10.2166/ wst.1986.0190.

29. Poreda, R. J., Haszeldine, R. S., Shipton, Z. K., Wilkinson, M., Gilfillan, S. M. V., \& Nelson, S. T. (2011). He and Ne as tracers of natural $\mathrm{CO} 2$ migration up a fault from a deep reservoir. International Journal of Greenhouse Gas Control, 5(6), 1507-1516. http://dx.doi.org/10.1016/j.ijggc.2011.08.008.

30. Roberts, J. J., Gilfillan, S. M., Stalker, L., \& Naylor, M. (2017). Geochemical tracers for monitoring offshore $\mathrm{CO} 2$ stores. International Journal of Greenhouse Gas Control, 65(July), 218-234. http://dx.doi.org/10.1016/j.ijggc.2017.07.021.

31. Hillebrand, O., Nödler, K., Sauter, M., \& Licha, T. (2015). Multitracer experiment to evaluate the attenuation of selected organic micropollutants in a karst aquifer. The Science of the Total Environment, 506-507, 338-343. http://dx.doi.org/10.1016/j. scitotenv.2014.10.102. PMid:25460968.

32. Riley, E. A., Gould, T., Hartin, K., Fruin, S. A., Simpson, C. D., Yost, M. G., \& Larson, T. (2016). Ultrafine particle size as a tracer for aircraft turbine emissions. Atmospheric Environment, 
139, 20-29. http://dx.doi.org/10.1016/j.atmosenv.2016.05.016. PMid:27795692.

33. Lee, J., Nez, V. E., Feng, X., Kirchner, J. W., Osterhuber, R., $\&$ Renshaw, C. E. (2008). A study of solute redistribution and transport in seasonal snowpack using natural and artificial tracers. Journal of Hydrology, 357(3-4), 243-254. http://dx.doi. org/10.1016/j.jhydrol.2008.05.004.

34. Kleimeyer, J. A., Rose, P. E., \& Harris, J. M. (2001). Determination of ultratrace-level fluorescent tracer concentrations in environmental samples using a combination of HPLC separation and laser-excited fluorescence multiwavelength emission detection: application to testing of geothermal well brines. Applied Spectroscopy, 55(6), 690-700. http://dx.doi. org/10.1366/0003702011952613.

35. Villela, J. M., Esteves Nogueira, A., Oliveira, C. R., \& Crestana, S. (2017). Desenvolvimento de traçadores para identificação de fontes de sendimentos. In Anais do IX Workshop de Nanotecnologia Aplicada ao Agronegócio (pp. 645-648). São Carlos: Embrapa Instrumentação. Retrieved in 2021, January 7, from https://www.embrapa.br/busca-de-publicacoes/-/ publicacao/1081640/desenvolvimento-de-tracadores-paraidentificacao-de-fontes-de-sendimentos

36. Ju, Y. J., Beaubien, S. E., Lee, S. S., Kaown, D., Hahm, D., Lee, S., Park, I. W., Park, K., Yun, S. T., \& Lee, K. K. (2019). Application of natural and artificial tracers to constrain $\mathrm{CO} 2$ leakage and degassing in the K-COSEM site, South Korea. International Journal of Greenhouse Gas Control, 86, 211-225. http://dx.doi.org/10.1016/j.ijggc.2019.05.002.

37. Zemel, B. (1995). Tracers in the oil field. Burlington: Elsevier.

38. Guido, Z., McIntosh, J. C., Papuga, S. A., \& Meixner, T. (2016). Seasonal glacial meltwater contributions to surface water in the Bolivian Andes: a case study using environmental tracers. Journal of Hydrology: Regional Studies, 8, 260-273. http:// dx.doi.org/10.1016/j.ejrh.2016.10.002.

39. Serres-Piole, C., Preud'homme, H., Moradi-Tehrani, N., Allanic, C., Jullia, H., \& Lobinski, R. (2012). Water tracers in oilfield applications: guidelines. Journal of Petroleum Science Engineering, 98-99, 22-39. http://dx.doi.org/10.1016/j. petrol.2012.08.009.

40. Hong, B., Panday, N., Shen, J., Wang, H. V., Gong, W., \& Soehl, A. (2010). Modeling water exchange between Baltimore Harbor and Chesapeake Bay using artificial tracers: seasonal variations. Marine Environmental Research, 70(1), 102-119. http://dx.doi. org/10.1016/j.marenvres.2010.03.010. PMid:20409577.

41. Heilweil, V. M., Solomon, D. K., \& Gardner, P. M. (2006). Borehole environmental tracers for evaluating net infiltration and recharge through desert bedrock. Vadose Zone Journal, 5(1), 98-120. http://dx.doi.org/10.2136/vzj2005.0002.

42. Geyer, T., Birk, S., Licha, T., Liedl, R., \& Sauter, M. (2007). Multitracer test approach to characterize reactive transport in karst aquifers. Ground Water, 45(1), 36-45. http://dx.doi. org/10.1111/j.1745-6584.2006.00261.x. PMid:17257337.

43. Sanford, W. E., Aeschbach-Hertig, W., \& Herczeg, A. L. (2011). Preface: insights from environmental tracers in groundwater systems. Hydrogeology Journal, 19(1), 1-3. http://dx.doi. org/10.1007/s10040-010-0687-9.

44. Leibundgut, C., Maloszewski, P., \& Kulls, C. (2009). Tracers in hydrology (1st ed.). Chichester: Wiley-Blackwell.

45. Brüschweiler, B. (2007). Markierstoffe im Bereich von Trinkwasserfassungen. Gas, Wasser, Abwasser, 87(5), 355-359. Retrieved in 2021, January 7, from http://scholar.google.com/ scholar?hl=en\&btnG=Search\&q=intitle:Markierstoffe $+\mathrm{im}+\mathrm{B}$ ereich+von+Trinkwasserfassungen\#0

46. Zhijiang, C., Cong, Z., Jie, G., Qing, Z., \& Kongyin, Z. (2018). Electrospun carboxyl multi-walled carbon nanotubes grafted polyhydroxybutyrate composite nanofibers membrane scaffolds: Preparation, characterization and cytocompatibility. Materials Science and Engineering C, 82, 29-40. http://dx.doi. org/10.1016/j.msec.2017.08.005. PMid:29025660.

47. Cruz-Tato, P., Ortiz-Quiles, E. O., Vega-Figueroa, K., SantiagoMartoral, L., Flynn, M., Díaz-Vázquez, L. M., \& Nicolau, E. (2017). Metalized nanocellulose composites as a feasible material for membrane supports: design and applications for water treatment. Environmental Science \& Technology, 51(8), 4585-4595. http://dx.doi.org/10.1021/acs.est.6b05955. PMid:28318247.

48. Fujii, T., Yano, T., Nakamura, K., \& Miyawaki, O. (2001). The sol-gel preparation and characterization of nanoporous silica membrane with controlled pore size. Journal of Membrane Science, 187(1-2), 171-180. http://dx.doi.org/10.1016/S03767388(01)00338-6.

49. Liu, F., Hashim, N. A., Liu, Y., Abed, M. R. M., \& Li, K. (2011). Progress in the production and modification of PVDF membranes. Journal of Membrane Science, 375(1-2), 1-27. http://dx.doi.org/10.1016/j.memsci.2011.03.014.

50. Rojano-Molina, M. G., Domínguez-Díaz, M., MartinezValencia, H., Escorcia-García, J., \& Balderas-Valadez, R. F. (2016). The hydrophilic to superhydrophilic change induced by polyhydroxybutyrate in polyethylene glycol:polyhydroxybutyrate electrospun samples by plasma treatment. MRS Advances, 1(29), 2125-2131. http://dx.doi.org/10.1557/adv.2016.423.

51. Ong, Y. T., Ahmad, A. L., Zein, S. H. S., Sudesh, K., \& Tan, S. H. (2011). Poly(3-hydroxybutyrate)-functionalised multiwalled carbon nanotubes/chitosan green nanocomposite membranes and their application in pervaporation. Separation and Purification Technology, 76(3), 419-427. http://dx.doi. org/10.1016/j.seppur.2010.11.013.

52. Lin, X., Li, S., Jung, J., Ma, W., Li, L., Ren, X., Sun, Y., \& Huang, T. S. (2019). PHB/PCL fibrous membranes modified withSiO2@TiO2-based core@shell composite nanoparticles for hydrophobic and antibacterial applications. RSC Advances, 9(40), 23071-23080. http://dx.doi.org/10.1039/C9RA04465E.

53. Sousa, W. J. B., Barbosa, R. C., Fook, M. V. L., Filgueira, P. T. D., \& Tomaz, A. F. (2017). Membranas de polihidroxibutirato com hidroxiapatita para utilização como biomaterial. Revista Materia, 22(4). http://dx.doi.org/10.1590/s1517-707620170004.0236.

54. Müller, D., Cercená, R., Gutiérrez Aguayo, A. J., Porto, L. M., Rambo, C. R., \& Barra, G. M. O. (2016). Flexible PEDOTnanocellulose composites produced by in situ oxidative polymerization for passive components in frequency filters. Journal of Materials Science Materials in Electronics, 27(8), 8062-8067. http://dx.doi.org/10.1007/s10854-016-4804-y.

55. Sabir, A., Islam, A., Shafiq, M., Shafeeq, A., Butt, M. T. Z., Ahmad, N. M., Sanaullah, K., \& Jamil, T. (2015). Novel polymer matrix composite membrane doped with fumed silica particles for reverse osmosis desalination. Desalination, 368 , 159-170. http://dx.doi.org/10.1016/j.desal.2014.12.041.

56. Varanasi, S., Low, Z. X., \& Batchelor, W. (2015). Cellulose nanofibre composite membranes - Biodegradable and recyclable UF membranes. Chemical Engineering Journal, 265(1), 138146. http://dx.doi.org/10.1016/j.cej.2014.11.085.

57. Lin, X., Yin, M., Liu, Y., Li, L., Ren, X., Sun, Y., \& Huang, T. S. (2018). Biodegradable polyhydroxybutyrate/poly- $\varepsilon-$ caprolactone fibrous membranes modified by silica composite hydrol for super hydrophobic and outstanding antibacterial application. Journal of Industrial and Engineering Chemistry, 63, 303-311. http://dx.doi.org/10.1016/j.jiec.2018.02.031.

58. Karpova, S. G., Iordanskii, A. L., Popov, A. A., Lomakin, S. M., \& Shilkina, N. G. (2015). A case study on biodegradable compositions based on natural polymers. In E. Klodzinska (Ed.), Functional materials: properties, performance and 
evaluation (pp. 235-247). New York: Apple Academic Press. https://doi.org/10.1201/b18183.

59. Reis, E. C. C., Borges, A. P. B., Oliveira, P. M., Bicalho, S. M. C. M., Reis, A. M., \& Silva, C. L. (2012). Development and characterization of rigid, resorbable and osteoconductive membranes made of polyhydroxybutyrate and hydroxyapatite for periodontal regeneration. Polímeros: Ciência e Tecnologia, 22(1), 73-79. https://doi.org/10.1590/S0104-14282012005000007.

60. Venault, A., Subarja, A., \& Chang, Y. (2017). Zwitterionic polyhydroxybutyrate electrospun fibrous membranes with a compromise of bioinert control and tissue-cell growth. Langmuir, 33(9), 2460-2471. http://dx.doi.org/10.1021/acs. langmuir.6b04683. PMid:28177247.

61. Karahaliloğlu, Z., Ercan, B., Taylor, E. N., Chung, S., Denkbaş, E. B., \& Webster, T. J. (2015). Antibacterial nanostructured polyhydroxybutyrate membranes for guided bone regeneration. Journal of Biomedical Nanotechnology, 11(12), 2253-2263. http://dx.doi.org/10.1166/jbn.2015.2106. PMid:26510318.

62. Krucinska, I., Zywicka, B., Komisarczyk, A., Szymonowicz, M., Kowalska, S., Zaczynska, E., Struszczyk, M., Czarny, A., Jadczyk, P., Uminska-Wasiluk, B., Rybak, Z., \& Kowalczuk, M. (2017). Biological properties of low-toxicity PLGA and PLGA/PHB fibrous nanocomposite implants for osseous tissue regeneration. Part I: evaluation of potential biotoxicity. Molecules, 22(12), 1-25. http://dx.doi.org/10.3390/molecules22122092. PMid:29186078.

63. Ma, B., Jin, M., Liang, X., \& Li, J. (2018). Processus de mélange et de minéralisation des eaux souterraines dans un bassin désertique montagneux avec des oasis, dans le nordouest de la Chine: hydrogéochimie et indicateurs de traceurs environnementaux. Hydrogeology Journal, 26(1), 233-250. http://dx.doi.org/10.1007/s10040-017-1659-0.

64. Salehi, E., Madaeni, S. S., \& Heidary, F. (2012). Dynamic adsorption of $\mathrm{Ni}(\mathrm{II})$ and $\mathrm{Cd}(\mathrm{II})$ ions from water using 8-hydroxyquinoline ligand immobilized PVDF membrane: Isotherms, thermodynamics and kinetics. Separation and Purification Technology, 94, 1-8. http://dx.doi.org/10.1016/j. seppur.2012.04.004.

65. Villegas, M., Romero, A. I., Parentis, M. L., Castro Vidaurre, E. F., \& Gottifredi, J. C. (2016). Acrylic acid plasma polymerized poly(3-hydroxybutyrate) membranes for methanol/MTBE separation by pervaporation. Chemical Engineering Research \& Design, 109, 234-248. http://dx.doi.org/10.1016/j.cherd.2016.01.018.

66. Esposito, A. R., Duek, E. A. R., Lucchesi, C., Prazeres, L., \& Pezzin, A. P. T. (2010). Citocompatibilidade de blendas de poli(pdioxanona)/poli(hidroxi butirato) (PPD/PHB) para aplicações em engenharia de tecido cartilaginoso. Polímeros, 20(5), 383388. http://dx.doi.org/10.1590/S0104-14282010005000062.

67. Gredes, T., Wróbel-Kwiatkowska, M., Dominiak, M., Gedrange, T., \& Kunert-Keil, C. (2012). Osteogenic capacity of transgenic flax scaffolds. Biomedizinische Technik, 57(1), 53-58. http:// dx.doi.org/10.1515/bmt-2011-0035. PMid:22718592.

68. Çatıker, E., Stakleff, K. S., Carr, K. B., \& Sancaktar, E. (2016). Laser-perforated polymer films for possible use in tissue engineering. Surface Innovations, 4(1), 23-32. http://dx.doi. org/10.1680/jsuin.15.00019.

69. Jiang, B., Zheng, J., Lu, X., Liu, Q., Wu, M., Yan, Z., Qiu, S., Xue, Q., Wei, Z., Xiao, H., \& Liu, M. (2013). Degradation of organic dye by pulsed discharge non-thermal plasma technology assisted with modified activated carbon fibers. Chemical Engineering Journal, 215-216, 969-978. http:// dx.doi.org/10.1016/j.cej.2012.11.046.

70. Tematio, C., Bassas-Galia, M., Fosso, N., Gaillard, V., Mathieu, M., Zinn, M., Staderini, E., \& Schintke, S. (2016). Design and characterization of conductive biopolymer nanocomposite electrodes for medical applications. Materials Science Forum,
879, 1921-1926. http://dx.doi.org/10.4028/www.scientific.net/ MSF.879.1921.

71. Schettini, E., Santagata, G., Malinconico, M., Immirzi, B., Scarascia Mugnozza, G., \& Vox, G. (2013). Recycled wastes of tomato and hemp fibres for biodegradable pots: physicochemical characterization and field performance. Resources, Conservation and Recycling, 70, 9-19. http://dx.doi.org/10.1016/j. resconrec.2012.11.002.

72. Zhijiang, C., Cong, Z., Ping, X., Jie, G., \& Kongyin, Z. (2018). Calcium alginate-coated electrospun polyhydroxybutyrate/ carbon nanotubes composite nanofibers as nanofiltration membrane for dye removal. Journal of Materials Science, 53(20), 14801-14820. http://dx.doi.org/10.1007/s10853-0182607-7.

73. Zhang, Y., Price, G. W., Jamieson, R., Burton, D., \& Khosravi, K. (2017). Sorption and desorption of selected non-steroidal anti-inflammatory drugs in an agricultural loam-textured soil. Chemosphere, 174, 628-637. http://dx.doi.org/10.1016/j. chemosphere.2017.02.027. PMid:28199939.

74. Sengupta, I. N. (1992). Bibliometrics, informetrics, scientometrics and librametrics: an overview. Libri, 42(2), 75-98. http://dx.doi. org/10.1515/libr.1992.42.2.75.

75. Café, L., \& Bräscher, M. (2008). Organização da informação e bibliometria. Encontros Bibli: Revista Eletrônica de Biblioteconomia e Ciência Da Informação, 13, 54-75.

76. Araujo, A. S., \& Azevedo, D. C. S. (2004). Fundamentos de adsorção. In Anais do $5^{\circ}$ Encontro Brasileiro Sobre Adsorção. Natal.

77. Waltman, L., van Eck, N. J., \& Noyons, E. C. M. (2010). A unified approach to mapping and clustering of bibliometric networks. Journal of Informetrics, 4(4), 629-635. http://dx.doi. org/10.1016/j.joi.2010.07.002.

78. Yu, D., Wang, W., Zhang, W., \& Zhang, S. (2018). A bibliometric analysis of research on multiple criteria decision making. Current Science, 114(4), 747-758. http://dx.doi.org/10.18520/ $\mathrm{cs} / \mathrm{v} 114 / \mathrm{i} 04 / 747-758$.

79. van Eck, N. J., Waltman, L., Dekker, R., \& van Den Berg, J. (2010). A comparison of two techniques for bibliometric mapping: multidimensional scaling and VOS. Journal of the American Society for Information Science and Technology, 61(12), 2405-2416. http://dx.doi.org/10.1002/asi.21421.

80. Martínez-López, F. J., Merigó, J. M., Valenzuela-Fernández, L., \& Nicolás, C. (2018). Fifty years of the European Journal of Marketing: a bibliometric analysis. European Journal of Marketing, 52(1-2), 439-468. http://dx.doi.org/10.1108/EJM11-2017-0853.

81. Echeverry, S. M., \& Marques, A. (2019). Integrated LCA and GIS in the energy sector: a bibliographic approach. Revista Espaço Energia, 31, 12-16.

82. Guo, Y. M., Huang, Z. L., Guo, J., Li, H., Guo, X. R., \& Nkeli, M. J. (2019). Bibliometric analysis on smart cities research. Sustainability, 11(13), 3606. http://dx.doi.org/10.3390/ su11133606.

83. Pan, X., Yan, E., Cui, M., \& Hua, W. (2018). Examining the usage, citation, and diffusion patterns of bibliometric mapping software: A comparative study of three tools. Journal of Informetrics, 12(2), 481-493. http://dx.doi.org/10.1016/j. joi.2018.03.005.

84. Aghaei, A., Salehi, H., Md Yunus, M. M., Farhadi, H., Fooladi, M., Farhadi, M., \& Ale Ebrahim, N. (2013). A comparison between two main academic literature collections: web of science and scopus databases. Asian Social Science, 9(5), 18-26. http://dx.doi.org/10.5539/ass.v9n5p18.

85. Gruber, W., \& Deuticke, B. (1973). Comparative aspects of phosphate transfer across mammalian erythrocyte membranes. 
The Journal of Membrane Biology, 13(1), 19-36. http://dx.doi. org/10.1007/BF01868218. PMid:4752450.

86. Reide Corbett, D., Dillon, K., \& Burnett, W. (2000). Tracing groundwater flow on a barrier island in the north-east Gulf of Mexico. Estuarine, Coastal and Shelf Science, 51(2), 227-242. http://dx.doi.org/10.1006/ecss.2000.0606.

87. Dzikowski, M., \& Delay, F. (1992). Simulation algorithm of time-dependent tracer test systems in hydrogeology. Computers \& Geosciences, 18(6), 697-705. http://dx.doi.org/10.1016/00983004(92)90004-B.

88. World Health Organization - WHO. (2004). Fourth Ministerial Conference on Environment and Health. Geneva.

89. Dao, V., Langella, I., \& Carbo, J. (2011). From green to sustainability: information Technology and an integrated sustainability framework. The Journal of Strategic Information Systems, 20(1), 63-79. http://dx.doi.org/10.1016/j.jsis.2011.01.002.

90. Hillebrand, O., Nödler, K., Licha, T., Sauter, M., \& Geyer, T. (2012). Identification of the attenuation potential of a karst aquifer by an artificial dualtracer experiment with caffeine. Water Research, 46(16), 5381-5388. http://dx.doi.org/10.1016/j. watres.2012.07.032. PMid:22877878.

91. Zhang, S. F., Splendiani, A., Santos, L. M. F., \& Livingston, A. G. (1998). Determination of pollutant diffusion coefficients in naturally formed biofilms using a single tube extractive membrane bioreactor. Biotechnology and Bioengineering, 59(1), 80-89. http:// dx.doi.org/10.1002/(SICI)1097-0290(19980705)59:1<80::AIDBIT11>3.0.CO;2-6. PMid:10099317.

92. Didegah, F., \& Thelwall, M. (2013). Which factors help authors produce the highest impact research? Collaboration, journal and document properties. Journal of Informetrics, 7(4), 861873. http://dx.doi.org/10.1016/j.joi.2013.08.006.
93. Organisation for Economic Co-operation and Development - OCDE. (2020). Research and development (R\&D): gross domestic spending on $R \& D$. Retrieved in 2021, January 7 , from http://data.oecd.org/rd/gross-domesticspending-on-r-d. htm

94. Zharkova, I. I., Efremov, Y. M., Bagrov, D. V., Zernov, A. L., Andreeva, N. V., Shaitan, K. V., Bonartsev, A. P., Boschomjiev, A. P., Makhina, T. K., Myshkina, V. L., Voinova, V. V., Yakovlev, S. G., Filatova, E. V., Ivanov, E. A., \& Bonartseva, G. A. (2012). The effect of poly(3-hydroxybutyrate) modification by poly(ethylene glycol) on the viability of cells grown on the polymer films. Biomeditsinskaya Khimiya, 58(5), 579-591. http://dx.doi.org/10.18097/pbmc20125805579. PMid:23289300.

95. Kunert-Keil, C., Gredes, T., Meyer, A., Wróbel-Kwiatkowska, M., Dominiak, M., \& Gedrange, T. (2012). The survival and proliferation of fibroblasts on biocomposites containing genetically modified flax fibers: an in vitro study. Annals of Anatomy, 194(6), 513-517. http://dx.doi.org/10.1016/j. aanat.2011.12.006. PMid:22377281.

96. Yan, L., Kasal, B., \& Huang, L. (2016). A review of recent research on the use of cellulosic fibres, their fibre fabric reinforced cementitious, geo-polymer and polymer composites in civil engineering. Composites. Part B, Engineering, 92, 94-132. http://dx.doi.org/10.1016/j.compositesb.2016.02.002.

97. Van-Eck, N. J., \& Waltman, L. (2017). Manual for VOSviewer versión 1.6.6. Leiden: Universiteit Leiden.

98. Elliot, T. (2014). Environmental tracers. Water, 6(11), 32643269. http://dx.doi.org/10.3390/w6113264.

Received: Jan. 07, 2021

Revised: Jan. 26, 2021

Accepted: Feb. 09, 2021 